Boletín de la Sociedad Geológica Mexicana

VOLUMEN 64, NÚM. 2, 2012, P. 161-169

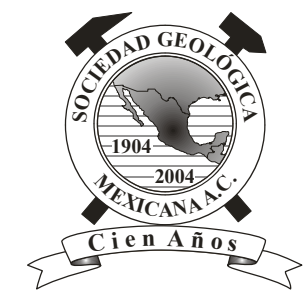

\title{
Stable Carbon Isotopes Applied to Vegetation Reconstruction in the Teotihuacan Valley, Mexico
}

\author{
Emily McClung de Tapia ${ }^{1, *}$, Carmen Cristina Adriano-Morán ${ }^{2}$ \\ ${ }^{1}$ Laboratorio de Paleoetnobotánica y Paleoambiente, Instituto de Investigaciones Antropológicas, Universidad Nacional Autónoma de \\ México, Ciudad Universitaria, 04510, México, D.F. \\ ${ }^{2}$ Posgrado en Ciencias Biológicas, Facultad de Ciencias, Universidad Nacional Autónoma de México, Ciudad Universitaria, 04510, \\ México, D.F. \\ *mcclung@servidor.unam.mx
}

\begin{abstract}
Stable carbon isotope values $\left(\delta^{13} \mathrm{C}\right)$ from organic material in soils and sediments suggest possible sources of carbon in the organic component and contribute to the development of hypotheses concerning the composition of regional vegetation. This paper explores the application of $\delta^{13} \mathrm{C}$ to the study of soils and sediments in conjunction with the analysis of plant remains in the Teotihuacan Valley, Mexico, located approximately $50 \mathrm{~km} \mathrm{NE}$ of Mexico City, known for the archaeological site of Teotihuacan, occupied between $c a$. AD 1-650. The ratios of ${ }^{13} \mathrm{C} /{ }^{12} \mathrm{C}$ from soil organic matter $(\mathrm{SOM})$ provide a complementary approach towards the analysis of past vegetation change in regions characterized by relatively poor preservation of plant macrofossils and pollen. The analysis of phytoliths recovered from soils and sediments offers an additional source of evidence for broad changes in environmental conditions based on changes in the relative proportions of $\mathrm{C} 3$ and $\mathrm{C} 4$ grasses. In this paper $\delta^{13} \mathrm{C}$ ratios obtained from SOM in profiles in the Teotihuacan Valley are compared with the results of phytolith analysis in the same horizons. The relative proportion of carbon derived from C4-CAMS (Crassulacean Acid Metabolism) plants was calculated. Phytolith analysis focused on the relative proportions of C3 (diagnostic phytoliths of the Pooideae subfamily of Poaceae) and C4 grass taxa (subfamilies Panicoideae, Chloridoideae and Aristodoideae). The $\delta^{13} \mathrm{C}$ ratios obtained from Tlajinga, located in an area of prehispanic irrigation south of the San Lorenzo River in the central Valley, indicate the predominance of C4-CAMS plants while phytoliths from the same horizons reflect a greater proportion of $\mathrm{C} 4$ grasses, although proportionally lower than isotopic indicators. The values of $\delta^{13} \mathrm{C}$ in SOM from Otumba, situated in close proximity to a river that also provided water for a prehispanic irrigation system, reflect a slightly lower predominance of C4-CAMS plants, and a slight increase in C4 grass phytoliths, with respect to Tlajinga. San Pablo provided evidence for the greatest predominance of C4-CAMS plants based on $\delta^{13} \mathrm{C}$ values in $\mathrm{SOM}$ whereas the phytoliths recovered from the same horizons indicate a higher proportion of $\mathrm{C} 3$ grasses. In general, the isotopic signatures reported here indicate changes in relative proportions of C4-CAMS plants, suggesting variability in the response of vegetation to local conditions, with a predominance of C4-CAMS plants in soil organic matter and considerable variability in proportions of $\mathrm{C} 4$ grass phytoliths in the contexts analyzed.
\end{abstract}

Keywords: Stable carbon isotopes, buried soils, Teotihuacan, phytoliths.

\section{Resumen}

Los valores de los isótopos estables de carbono $\left(\delta^{13} \mathrm{C}\right)$ del material orgánico presente en suelos y sedimentos, sugieren las posibles fuentes de carbono, contribuyendo al desarrollo de hipótesis referentes a la composición de la vegetación regional. Este trabajo explora la utilidad del $\delta^{13} \mathrm{C}$ para el estudio de los suelos y sedimentos en conjunto con los resultados de los análisis de los restos de plantas del Valle de Teotihuacan, México, localizado aproximadamente a $50 \mathrm{~km}$ al noroeste de la Ciudad de México, conocido por el sitio arqueológico de Teotihuacan, ocupado entre ca. AD 1-650. Las proporciones de los isótopos de ${ }^{13} \mathrm{C}^{12} \mathrm{C}$ de la materia orgánica del suelo (MOS), ofrecen un método complementario para el análisis del cambio de la vegetación en el pasado en regiones caracterizadas por 
una pobre conservación de macro-restos vegetales y de polen. El análisis de los fitolitos recuperados de suelos y sedimentos reporta una fuente adicional de evidencia de amplios cambios en las condiciones ambientales con base en las variaciones en los porcentajes relativos de pastos $C 3$ y C4. En este trabajo se comparan los valores de $\delta^{13} \mathrm{C}$ obtenidos de la materia orgánica de suelo de perfiles en el Valle de Teotihuacan con los fitolitos analizados en los mismos horizontes. Se calculó el porcentaje relativo de carbono derivado de plantas C4-CAMS (Crassulacean Acid Metabolism). El examen de los fitolitos se centró en los porcentajes relativos de los taxa de pastos C3 (fitolitos diagnósticos de la subfamilia Pooideae de Poaceae) y taxa de pastos C4 (subfamilias Panicoideae, Chloridoideae y Aristodoideae). Las proporciones de $\delta^{13} C$ de Tlajinga, situado en un área de irrigación prehispánica al sur del Río San Lorenzo en el sector sur del valle central, evidencian la predominancia de plantas C4-CAMS mientras que los fitolitos recuperados de los mismos horizontes indican un porcentaje mayor de pastos C4 pero proporcionalmente menor que los indicadores isotópicos. Los valores de $\delta^{13} \mathrm{C}$ en MOS obtenidos de Otumba, situado junto a un río que también suministraba agua a un sistema prehispánico de irrigación, refleja una predominancia ligeramente menor de plantas C4-CAMS, así como un ligero incremento en los fitolitos dominados por pastos C4, con respecto a Tlajinga. San Pablo proporcionó evidencia para la mayor predominancia de plantas C4-CAMS representados por los valores de $\delta^{13} \mathrm{C}$ en $\mathrm{MOS}$, mientras que los fitolitos recuperados de los mismos horizontes reflejan mayor proporción de pastos C3. En general, las firmas isotópicas reportadas señalan diferencias en los porcentajes relativos de plantas C4-CAMS, lo que sugiere una variabilidad en la respuesta de la vegetación a condiciones locales, con una predominancia de plantas C4-CAMS en la materia orgánica del suelo, mientras que los fitolitos señalan concentraciones muy variables de pastos C4 en los contextos estudiados.

Palabras clave: isotopos estables de carbono, suelos enterrados, Teotihuacan, fitolitos.

\section{Introduction}

Stable carbon isotope values $\left(\delta^{13} \mathrm{C}\right)$ from organic material in soils and sediments suggest possible sources of carbon in the organic component and contribute to the development of hypotheses concerning the composition of regional vegetation (Biedenbender et al., 2004; Boutton, 1996). Such data provide complementary information which, when combined with the determination of stratigraphic microand macrobotanical remains from archaeological contexts, broadens our perspective concerning past landscapes. This paper explores the application of $\delta^{13} \mathrm{C}$ to the study of soils and sediments in conjunction with the analysis of plant remains in the Teotihuacan Valley, Mexico (Figure 1). Building on the preliminary analyses of stable carbon isotopes from several soil profiles in the Teotihuacan region (Lounejeva-Baturina et al., 2006, 2007; Rivera-Uria et al., $2007), \delta^{13} \mathrm{C}$ values obtained from additional profiles in the same region (McClung de Tapia et al., 2005, SolleiroRebolledo et al., 2011) are examined in order to evaluate the evidence for vegetation change.

This area, located approximately $50 \mathrm{~km} \mathrm{NE}$ of Mexico City, is best known for the archaeological site of Teotihuacan, the earliest city of its size and density in the Americas, occupied between $c a$. AD 1-650. Although the prehispanic urban center of Teotihuacan represents a significant focus for our research, the results presented here are part of an attempt to establish a scenario of landscape transformation from the period of prehispanic occupation through the Colonial period, based on the analysis of sediments and associated plant remains, including macrobotanical remains, pollen and phytoliths (McClung de Tapia et al., 2003).

In a highly perturbed landscape such as the Teotihuacan Valley where paleoenvironmental studies are frequently limited by relatively poor preservation of plant macrofossils and pollen in predominantly alluvial soils, the ratio of ${ }^{13} \mathrm{C} /{ }^{12} \mathrm{C}$ provides a complementary approach towards the analysis of past vegetation change. Phytoliths recovered from soils and sediments offer an additional source of evidence for broad changes in environmental conditions based on the relative proportions of $\mathrm{C} 3$ and $\mathrm{C} 4$ grasses (McClung de Tapia et al., 2008). Macrobotanical remains are concentrated in the upper $50 \mathrm{~cm}$ of profiles for the most part, and pollen is often insufficient to permit quantitative analysis.

\section{2. ${ }^{13} \mathrm{C} /{ }^{12} \mathrm{C}$ ratios}

Stable carbon isotope ratios in soil organic matter (SOM) provide information regarding the kinds of plants (C3 and C4/CAMS - Crassulacean Acid Metabolism) that contributed to the organic component. In the Teotihuacan Valley this technique is employed to complement the evidence for vegetation change suggested by other proxies.

The ratio of ${ }^{13} \mathrm{C} /{ }^{12} \mathrm{C}$ may be used as an indicator of the origin of organic carbon in soils and sediments (Boutton, 1996). Differences in the photosynthetic pathways of plant taxa, resulting in the characterization of Calvin-Benson Cycle (C3 or non-Krantz), Slack-Hatch Cycle (C4 or Krantz) and Crassulacean Acid Metabolism (CAM), are reflected in different proportions of ${ }^{13} \mathrm{C}$ with respect to ${ }^{12} \mathrm{C}$. $\delta^{13} \mathrm{C}$ ratios of $\mathrm{C} 3$ plants range from approximately $-32 \%$ to $-20 \%$ with a mean of $-27 \%$. The range for $\mathrm{C} 4$ plants varies between $-17 \%$ and $-9 \%$, with a mean of approximately $-13 \%$. The ratios for $\mathrm{C} 3$ and $\mathrm{C} 4$ plant taxa therefore differ from one another by roughly $-14 \%$. $\mathrm{C} 4$ photosynthesis represents a more efficient form of $\mathrm{CO}_{2}$ fixation than the $\mathrm{C} 3$ pathway. It has been suggested that $\mathrm{C} 4$ plants evolved 


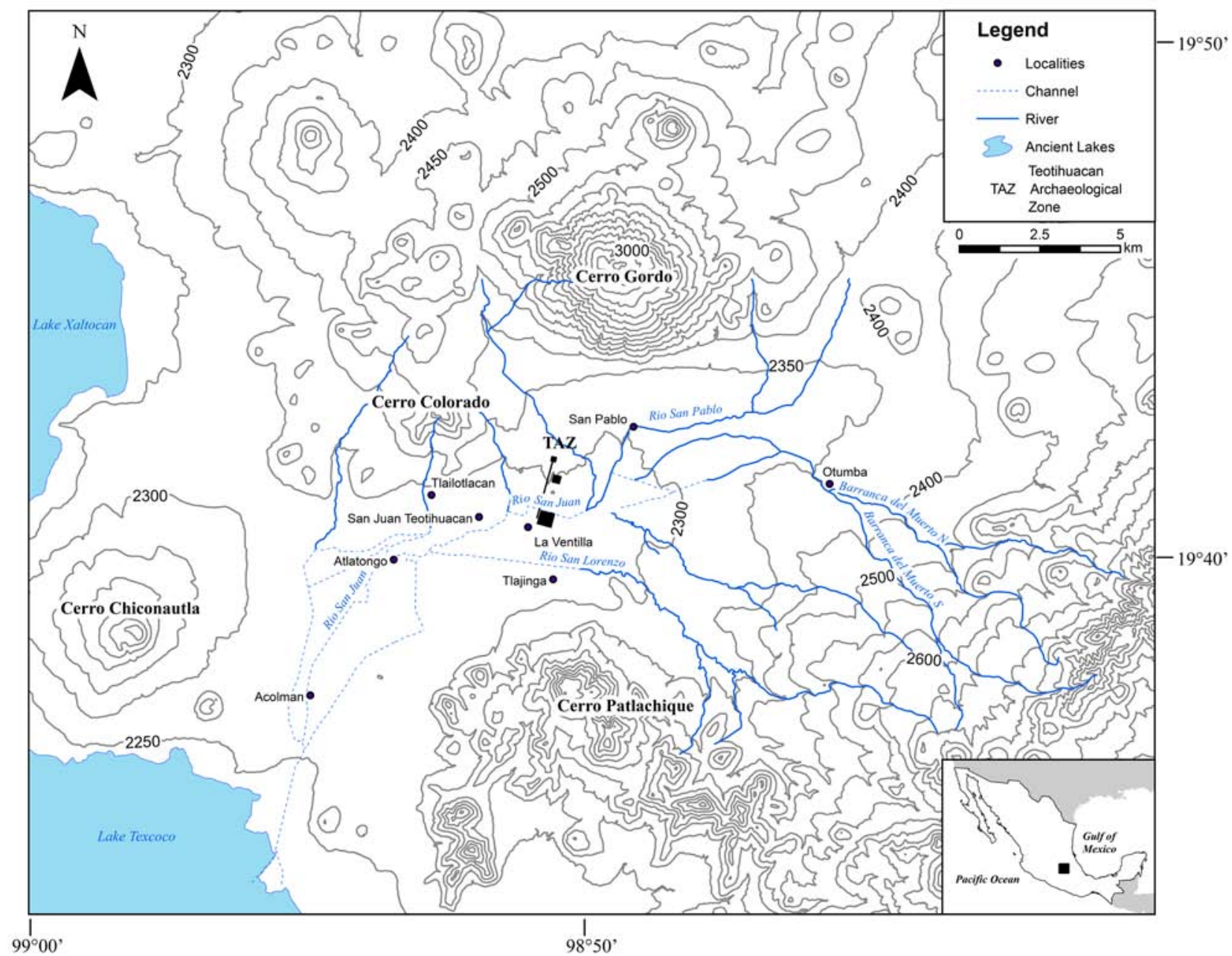

Figure 1. The Teotihuacan Valley, Mexico, showing locations of profiles mentioned in the text. (Map by Rodrigo Tapia-McClung).

in arid environments where tolerance of high intensity of light, temperature and hydric stress would confer a selective advantage (Gould and Shaw, 1983).

CAMs plants, mainly succulents and Cactaceae, close stomata during the day and fix $\mathrm{CO}_{2}$ at night by means of a mechanism similar to that of $\mathrm{C} 4$ plants, thus reducing water loss. Some species are able to shift to a $\mathrm{C} 3$ daytime photosynthetic cycle when environmental conditions vary whereas other species always incorporate $\mathrm{CO}_{2}$ at night (Lajtha and Marshall, 1994). The latter have $\delta^{13} \mathrm{C}$ values similar to $\mathrm{C} 4$ plants while the former range from $-28 \%$ to $-10 \%$. The CAMs taxa analyzed in the Teotihuacan Valley have a mean $\delta^{13} \mathrm{C}$ ratio of $-13.30 \%$ (Lounejeva-Baturina et al., 2006). Thus $\delta^{13} \mathrm{C}$ ratios can be used to quantify aspects of vegetation dynamics in ecosystems, such as the changes in relative proportions of plants and, by association, the environmental conditions (e.g. temperature and humidity) within which they developed.

The carbon isotope ratio $\left(\delta^{13} \mathrm{C}\right)$ is conventionally expressed relative to the Pee Dee Belemnite (PDB) standard and results are calculated on a per mil basis (parts per thousand, 0/00) (Boutton, 1996; Biedenbender et al., 2004). Boutton (1996) points out that there is little change in the $\delta^{13} \mathrm{C}_{\mathrm{PDP}}$ value of plant material as it decomposes and, consequently, the $\delta^{13} \mathrm{C}_{\mathrm{PDP}}$ values of soil organic carbon combine the relative contributions of plant material from $\mathrm{C} 3, \mathrm{C} 4$ and CAMS plant types to the soil organic carbon pool. Studies of differential decomposition rates, variability in atmospheric $\delta^{13} \mathrm{C}$, and isotope fractionation by microorganisms suggest that the potential increases of $\delta^{13} \mathrm{C}$ in bulk soil organic matter are lower than the difference between the ranges of $\mathrm{C} 3$ and $\mathrm{C} 4$ plants (Boutton, 1996; Kelly et al., 1998; Koch, 1998; Biedenbender et al., 2004). Thus, the basic assumption underlying the use of $\delta^{13} \mathrm{C}$ ratios as indicators of vegetation dynamics and related environmental change is that the primary influence on $\delta^{13} \mathrm{C}_{\mathrm{PDP}}$ of soil organic matter is the relative contribution of $\mathrm{C} 3$ versus $\mathrm{C} 4$ plants to the total net primary productivity of the community (Kerns et al., 2001). Nordt et al. (2007, 2008) emphasize the utility of stable carbon isotope analysis of SOM to ascertain the percent contribution of $\mathrm{C} 4$ plants as an indicator of temperature regime. 
Recent archaeological applications of $\delta^{13} \mathrm{C}$ in Mesoamerican archaeology have focused on detection of the presence of maize in soils (Webb et al., 2004, 2007; Wright, 2005; Johnson et al., 2007) or as residues in cooking vessels (Hart et al., 2007, 2009; Seinfeld et al., 2009). Stable carbon isotopes have been also used to reconstruct aspects of past human environments, based on the analysis of tooth enamel in mammals (Feranec, 2008), charcoal (Hall et al., 2008) and soil organic matter (Pessenda et al., 1998; Vågen et al., 2006; Wang et al., 2010).

Lounejeva-Baturina et al. $(2006,2007)$ undertook the first systematic determinations of stable carbon isotope ratios in soils in the Teotihuacan region, providing an initial view of the spatial and temporal differences in vegetation and thereby demonstrating the potential value of the technique for the study of vegetation change in the area through time. Additional values for $\delta^{13} \mathrm{C}$ were obtained at different stages of paleoenvironmental research in the Teotihuacan Valley, both as secondary products of AMS dating of bulk sediment samples from soil profiles as well as specific samples obtained from prehispanic agricultural surfaces (McClung de Tapia et al., 2005). The analysis of these data in conjunction with results reported by RiveraUria et al. (2007) and Solleiro-Rebolledo et al. (2011) is considered here together with other paleoethnobotanical indicators for past vegetation in the region.

Because radiocarbon dates on SOM represent the average age of all carbon atoms in an open system, SOM ages are always younger than the oldest organic matter and the age of initial pedogenesis (McClung de Tapia et al., 2005). In the present study, we selected two sites (Tlajinga and Otumba) with complementary prehispanic ceramic evidence (Pérez-Pérez, 2003) that allowed us to postulate the approximate time period during which the selected horizons were exposed in spite of seemingly incongruous radiocarbon dates. The third site, San Pablo, provided several in situ charcoal specimens (Rivera-Uria et al., 2007; Solleiro-Rebolledo et al., 2011; this work), the radiocarbon dates of which provide a basis for correlating the horizons with Tlajinga and Otumba.

Although $\delta^{13} \mathrm{C}$ ratios determined as secondary products of radiocarbon dating are often eliminated from studies seeking to detect paleoenvironmental trends based on published data, in order to avoid potential bias during sample preparation and analysis (Nordt et al., 2007, 2008), Solleiro-Rebolledo (personal communication) evaluated the consistency between the $\delta^{13} \mathrm{C}$ ratios obtained as byproducts of radiocarbon dating with those obtained directly from SOM from several profiles in the Teotihuacan Valley; no significant differences were found between the results.

\subsection{Objective of $\delta^{13} \mathrm{C}$ studies at Teotihuacan}

One of the goals of recent research in the Teotihuacan Valley is the recovery of evidence for changes in the landscape as a result of human impact during the prehispanic and Colonial period occupations. The analysis of $\delta^{13} \mathrm{C}$ ratios from selected soils in the Teotihuacan Valley was undertaken in order to detect evidence for vegetation change through time (Boutton, 1996; Biedenbender et al., 2004), considered an indicator of landscape modification. Phytolith analysis of the same soils was incorporated to compare with the results obtained from $\delta^{13} \mathrm{C}$ ratios.

Changes in stable carbon isotope ratios in SOM reflect vegetation dynamics. Assuming that the same plant taxa contribute both to soil organic material (SOM) and biogenic silica (phytoliths) present in soil horizons, a relatively close correspondence is expected between the $\delta^{13} \mathrm{C}$ ratios and the percentages of $\mathrm{C} 3$ and $\mathrm{C} 4$ plants indicated by the phytolith record. Thus, the $\delta^{13} \mathrm{C}$ ratios should be corroborated by evidence obtained from phytolith studies.

\section{Methodology: $\delta^{13} \mathrm{C}$ and Phytolith Analyses}

$\delta^{13} \mathrm{C}$ ratios were obtained from samples of bulk sediment from diverse contexts in the Teotihuacan Valley (Table 1). For this analysis profiles in which at least one dated buried A-horizon was present were selected. All of the samples considered in this study from which $\delta^{13} \mathrm{C}$ ratios were analyzed were processed by Beta Analytic, Inc., Miami, FL, USA. Pretreatment of sediments consisted of removal of apparent roots and mechanical dispersion in hot $\mathrm{HCl}$ to eliminate carbonates. Samples were subsequently rinsed until neutralized, dried and subject to combustion in a closed system. Conventional dates were obtained by benzene synthesis and counting; AMS measurements were based on carbon reduced to graphite. Charred materials were soaked in hot alkalai to remove humic acids, rinsed to neutrality, and subjected to an acid wash and again rinsed to neutrality. Conventional radiocarbon dates were obtained from sediments at Tlajinga and Otumba (McClung de Tapia et al., 2005); AMS dates were obtained from San Pablo.

The relative proportion of carbon derived from $\mathrm{C} 4-$ CAMS plants was calculated by the method described by Kelly et al. (1998) using the mean $\delta^{13} \mathrm{C}$ values for $\mathrm{C} 3$ and C4-CAMS plants in the Teotihuacan Valley reported by Lounejeva-Baturina et al. (2006):

$$
\% \mathrm{C} 4=\left(\delta_{\mathrm{SAMPLE}}-\delta_{\mathrm{C} 3} / \delta_{\mathrm{C} 4}-\delta_{\mathrm{C} 3}\right) * 100
$$

where $\delta_{\text {SAMPLE }}=\delta^{13} \mathrm{C}$ value of the sample, $\delta_{\mathrm{C} 3}=$ the mean $\delta^{13} \mathrm{C}$ value of $\mathrm{C} 3$ vegetation(-26.96\%), and $\delta_{\mathrm{C} 4}=$ the mean $\delta^{13} \mathrm{C}$ value of $\mathrm{C} 4$ vegetation(-13.29\%) in the study region.

Phytoliths recovered from the same contexts in the Teotihuacan Valley were considered for comparative analysis (Figure 2). Phytoliths from Tlajinga and Otumba were extracted using the $\mathrm{ZnBr}$ technique described by Pearsall (2000), whereas those from San Pablo were extracted using the protocol described by Madella et al. (1998). In this study, we focused on the relative proportions of C3 and C4 grass taxa. Diagnostic phytoliths of the 
Table 1. Horizons, conventional and calibrated radiocarbon dates and $\delta^{13} \mathrm{C}$ ratios from soil organic material (SOM) and Poaceae phytoliths associated with three sites in the Teotihuacan Valley. The percentage of $\mathrm{C} 4$ plants calculated from $\delta^{13} \mathrm{C}$ values is compared with the percentage indicated by phytoliths.

\begin{tabular}{|c|c|c|c|c|c|c|c|c|c|c|c|c|c|}
\hline Profile & $\begin{array}{c}\text { Elevation } \\
\text { (masl) }\end{array}$ & Horizon & Depth (cm) & No. BETA & $\begin{array}{c}\text { Conventional } \\
{ }^{14} \mathrm{C} \text { yrs BP }\end{array}$ & $\begin{array}{c}2 \text { Sigma Cal yrs } \\
\text { BC/AD }^{\mathrm{f}}\end{array}$ & $\delta^{13} \mathrm{C}$ & \%C4-CAMS & $\begin{array}{c}\text { Total } \\
\text { Poaceae }\end{array}$ & $\begin{array}{r}\text { Total } \\
(\% \mathrm{C} 3)\end{array}$ & $\begin{array}{l}\text { Total } \\
(\% \mathrm{C} 4)\end{array}$ & Associated ceramics & Occupation period ${ }^{\mathrm{h}}$ \\
\hline \multirow{8}{*}{$\begin{array}{l}\text { TLAJINGA } \\
19^{\circ} 39^{\prime} 57^{\prime \prime \prime} \mathrm{N} \\
98^{\circ} 50^{\prime} 41^{\prime \prime} \mathrm{W}\end{array}$} & \multirow{8}{*}{2288} & A & $0-35$ & & & & & & & & & Tlalmimilolpa -Aztec & \\
\hline & & $\mathrm{B}_{1}$ & $35-95$ & & & & & & & & & Tlalmimilolpa & \\
\hline & & $\mathrm{B}_{2}$ & $95-120$ & $142228^{\mathrm{a}}$ & $2890 \pm 50$ & cal BC $1257-928$ & -16.2 & 80.9 & 239 & $105(44 \%)$ & $134(56 \%)$ & Tlamimilolpa & \\
\hline & & $\mathrm{C}$ & $120-133$ & $142229^{\mathrm{a}}$ & $3370 \pm 60$ & cal BC 1873-1506 & -16.6 & 77.9 & 246 & $93(38 \%)$ & $153(62 \%)$ & Tlalmimilolpa-Xolalpan & \\
\hline & & $2 \mathrm{~A}_{11}$ & $133-158$ & $142230^{\mathrm{a}}$ & $2990 \pm 80$ & cal BC 1419-1005 & -15.7 & 84.7 & 243 & $129(53 \%)$ & $114(47 \%)$ & Miccaotli-Tlalmimilolpa & \\
\hline & & $2 \mathrm{~A}_{12}$ & $158-171$ & $142231^{a}$ & $3110 \pm 80$ & cal BC $1599-1128$ & -15.8 & 83.9 & 258 & $122(47 \%)$ & $136(53 \%)$ & Miccaotli-Tlalmimilolpa & \\
\hline & & 2B & $171-240$ & & & & & & & & & No ceramics & \\
\hline & & $2 \mathrm{C}$ & $240-260$ & & & & & & & & & & \\
\hline \multirow{7}{*}{$\begin{array}{l}\text { OTUMBA } \\
19^{\circ} 31^{\prime} 33^{\prime \prime} \mathrm{N} \\
98^{\circ} 45^{\prime} 46^{\prime \prime} \mathrm{W}\end{array}$} & \multirow{7}{*}{2318} & Ap & $0-55$ & & & & & & & & & Aztec-Colonial & \\
\hline & & $\mathrm{C} 1$ & $55-75$ & $142221^{\mathrm{a}}$ & $2980 \pm 60$ & cal BC $1390-1028$ & -17 & 74.9 & 225 & $89(40 \%)$ & $136(60 \%)$ & Aztec & \\
\hline & & $\mathrm{C} 2$ & $75-86$ & $142222^{\mathrm{a}}$ & $3540 \pm 60$ & cal BC 2031-1695 & -18.3 & 65 & 252 & $118(47 \%)$ & $134(53 \%)$ & Aztec & \\
\hline & & $2 \mathrm{~A}_{11}$ & $86-110$ & $142223^{\mathrm{a}}$ & $2890 \pm 60$ & cal BC 1263-916 & -17.9 & 68.1 & 264 & $93(35 \%)$ & $171(65 \%)$ & Mazapan- Early Aztec & \\
\hline & & $2 \mathrm{~A}_{12}$ & $110-137$ & $142224^{\mathrm{a}}$ & $3080 \pm 70$ & cal BC 1496-1130 & -19.3 & 57.6 & 245 & $83(34 \%)$ & $162(66 \%)$ & No Ceramics & \\
\hline & & $2 \mathrm{AC}$ & $137-196$ & & & & & & & & & & \\
\hline & & $2 \mathrm{C}$ & $196-222$ & & & & & & & & & & \\
\hline \multirow{12}{*}{$\begin{array}{l}\text { SAN PABLO } \\
19^{\circ} 42^{\prime} 31^{\prime \prime} \mathrm{N} \\
98^{\circ} 49^{\prime} 15^{\prime \prime} \mathrm{W}\end{array}$} & \multirow{12}{*}{2300} & Ap & $0-20$ & & & & & & & & & No ceramics & \\
\hline & & $\mathrm{C}$ & $20-27$ & & & & & & & & & & \\
\hline & & $2 \mathrm{~A}$ & $27-40$ & $219961^{b}$ & $2920 \pm 40$ & cal BC 1261-1006 & -17.7 & 69.6 & 447 & $307(69 \%)$ & $140(31 \%)$ & & \\
\hline & & $2 \mathrm{AC}$ & $40-62$ & & & & & & & & & & \\
\hline & & $2 \mathrm{C}$ & $62-90$ & & & & & & & & & & \\
\hline & & $3 \mathrm{~A}$ & $90-105$ & $219962^{\mathrm{b}}$ & $420 \pm 40^{\mathrm{e}}$ & cal AD 1420-1629 & -22 & 37.3 & 414 & $277(67 \%)$ & $137(33 \%)$ & & Aztec-Colonial \\
\hline & & $3 \mathrm{C}$ & $105-125$ & $293585^{\mathrm{d}}$ & $390 \pm 40^{\mathrm{e}}$ & cal AD 1437-1634 & -24.1 & 21.5 & 417 & $340(82 \%)$ & $77(18 \%)$ & & Aztec-Colonial \\
\hline & & $4 \mathrm{~A}$ & $125-175$ & $210760^{\mathrm{b}}$ & $2140 \pm 60$ & cal BC 370-41 & -16.7 & 77.2 & 312 & $218(70 \%)$ & $94(30 \%)$ & & \\
\hline & & & & $219963^{\mathrm{c}}$ & $620 \pm 40^{\mathrm{e}}$ & $\mathrm{cal}$ AD 1288-1405 & -23.3 & 27.5 & & & & & \multirow[t]{4}{*}{ Aztec } \\
\hline & & $4 \mathrm{AE}$ & $175-205$ & $293586^{d}$ & $2060 \pm 40$ & cal BC 184-AD 24 & -15.7 & 84.7 & 297 & $180(61 \%)$ & $117(39 \%)$ & & \\
\hline & & $5 \mathrm{~A}$ & $205-230$ & $261617^{c}$ & $2980 \pm 40$ & cal BC $1374-1056$ & -16.7 & 77.2 & 289 & $180(62 \%)$ & $109(38 \%)$ & & \\
\hline & & $5 \mathrm{Bk}$ & $230-260$ & & & & & & & & & & \\
\hline
\end{tabular}

a McClung de Tapia et al., 2005

${ }^{\mathrm{b}}$ Rivera-Uria et al., 2007

c Solleiro-Rebolledo et al., 2011

d This work

${ }^{\mathrm{e}}$ Charred material

${ }^{\mathrm{f}}$ Calibrations based on Intca109.14c (Stuiver and Reimer, 1993; Reimer et al., 2009)

g \%C4-CAMS calculated based on $\mathrm{C} 3=-26.96$ and $\mathrm{C} 4-\mathrm{CAMS}=-13.67$, mean values for Teotihucan region vegetation (Lounejeva-Baturina et al., 2006)

${ }^{\mathrm{h}}$ Approximate occupation based on Radiocarbon ages of in situ charred material

Pooideae subfamily of Poaceae were grouped as $\mathrm{C} 3$, whereas those corresponding to the Panicoideae, Chloridoideae and Aristodoideae subfamilies were grouped as $\mathrm{C} 4$. With the exception of a single genus, all of the genera of Poaceae corresponding to the subfamily Panicoideae reported in the Teotihuacan region (Castilla-Hernández and Tejero-Diez, 1987) utilize the $C 4$ photosynthetic pathway (Watson and Dallwitz, 1992).

\section{Results}

Table 1 summarizes the $\delta^{13} \mathrm{C}$ ratios from soil organic material (SOM) and Poaceae phytoliths associated with the three sites studied in the Teotihuacan Valley: Tlajinga, Otumba and San Pablo. The percentage of C4-CAMS plants calculated from $\delta^{13} \mathrm{C}$ values are compared with the proportion of $\mathrm{C} 4$ grasses (Poaceae) indicated by phytoliths recovered from the same horizons.

Tlajinga (Figure 3a), situated approximately 500 $m$ south of the Rio San Lorenzo, is located in an area which is dominated today by nopal orchards (Opuntia sp.). However, this area conformed part of a prehispanic irrigation system (Nichols, 1987; Nichols et al., 1991). The earliest horizon for which $\delta^{13} \mathrm{C}$ ratios are available $\left(2 \mathrm{~A}_{12}\right)$ reports a value of $-15.8 \%$ ( $83.9 \% \mathrm{C} 4$-CAMS $)$, which is entirely consistent with the overlying $2 \mathrm{~A}_{11}$ horizon (-15.7\%o, 84.7\% C4-CAMS). These same horizons report $53 \%$ and $47 \% \mathrm{C} 4$ grass phytoliths respectively, with a slight predominance of $\mathrm{C} 3$ in $2 \mathrm{~A}_{11}$. In both horizons, the proportion of $\mathrm{C} 4$ grass phytoliths is significantly lower than that suggested by $\delta^{13} \mathrm{C}$ ratios. Above this, the values for the $\mathrm{C}$ horizon $(-16.6 \%, 77.9 \% \mathrm{C} 4-\mathrm{CAMS})$ and overlying $\mathrm{B}_{2}(-16.2 \%, 80.9 \%$ C4-CAMS ) indicate a slight decrease in $\mathrm{C} 4$ vegetation. However, phytoliths continue to indicate a considerably lower proportion of $\mathrm{C} 4$ grasses with respect to $\delta^{13} \mathrm{C}$ values: $62 \%$ for the $\mathrm{C}$ horizon and $56 \%$ for the overlying $\mathrm{B}_{2}$. Both the $2 \mathrm{~A}_{11}$ and $2 \mathrm{~A}_{12}$ horizons are associated with Teotihuacan period ceramics corresponding to the Miccaotli and Tlamimilolpa phases (Pérez-Pérez, 2003) dated to approximately AD 150-350, while the overlying $\mathrm{C}$ horizon contains Tlamimilolpa-Xolalpan phase materials (approximately AD 200-500) and predominantly Tlamimilolpa (AD 200-350) in $\mathrm{B}_{2}$. Surface ceramics include Tlamimilolpa together with Late Aztec phase (AD 13501520) materials. 


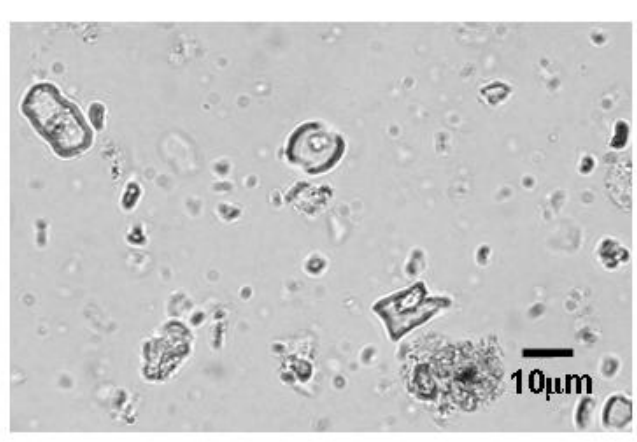

(a)

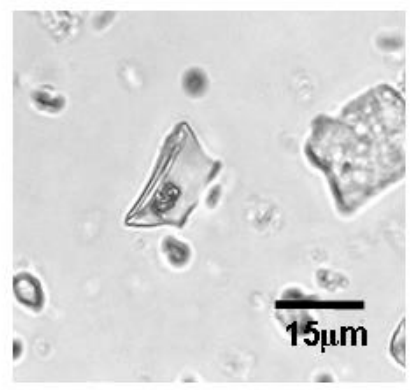

(c)

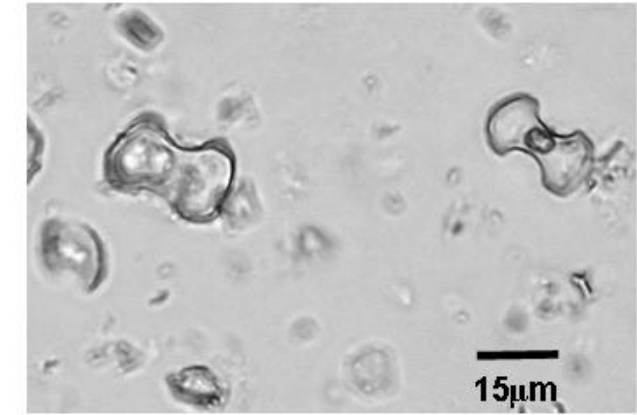

(b)

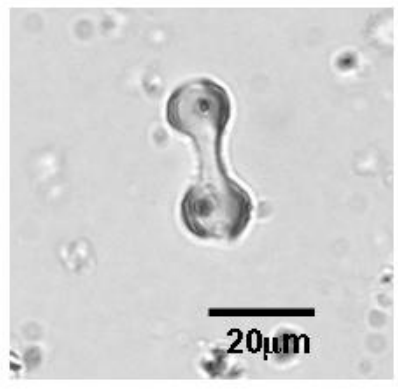

(d)

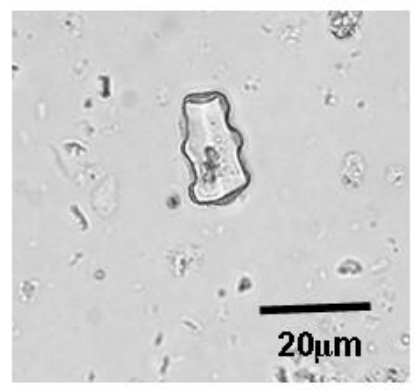

(e)

Figure 2. Phytoliths from $\mathrm{C} 3$ and $\mathrm{C} 4$ grasses (Poaceae) identified in the soils and sediments of Teotihuacan Valley. (a) Chloridoideae saddle-shape, 40x; (b) Pooideae bilobates, 40x; (c) Pooideae rondel, 40x; (d) Aristoideae bilobate, 40x and (e) Pooideae wavy trapezoid, 40x.

The profile at Otumba (Figure $3 b$ ) is situated approximately $100 \mathrm{~m} \mathrm{~N}$ of the Barranca del Muerto, adjacent to the Aztec site of Otompan, at a distance of 20 $\mathrm{m}$ from archaeological excavations undertaken by Charlton (1990) in remnants of floodwater irrigation canals and fields corresponding to the Aztec occupation. Modern plants on the surface are largely opportunistic taxa associated with abandoned fields, including ChenopodiaceaeAmaranthaceae and Asteraceae. The available $\delta^{13} \mathrm{C}$ ratios indicate values of $-19.3 \%$ ( $57 \%$ C4-CAMS) for $2 \mathrm{~A}_{12}$ and $-17.9 \%$ ( $68 \%$ C4-CAMS) in $2 \mathrm{~A}_{11}$. Phytoliths reflect the predominance of $\mathrm{C} 4$ grass taxa, $66 \%$ in $2 \mathrm{~A}_{12}$ and $65 \%$ in $2 \mathrm{~A}_{11}$. The overlying horizons are characterized by a slight decrease, $-18.3 \%, 65 \%$ C4-CAMS in $\mathrm{C}_{2}$, followed by a subsequent increase, $-17 \%, 74.9 \%$ C4-CAMS in $\mathrm{C}_{1}$. A similar tendency is evident in $\mathrm{C}_{2}$ where phytoliths from $\mathrm{C} 4$ grasses comprise $53 \%$, followed by a light increase in $\mathrm{C}_{1}$ $(60 \% \mathrm{C} 4)$.

Ceramics associated with these horizons point to a Mazapan (Toltec)-Early Aztec occupation (approximately AD 950-1350) corresponding to the $2 \mathrm{~A}_{11}$ horizon followed by a Late Aztec occupation (ca. AD 1350-1520) in the overlying $\mathrm{C}_{2}$ and $\mathrm{C}_{1}$ horizons.

The San Pablo profile (Figure 3c) is located NE of the modern community of San Martín de las Pirámides on a terrace at the edge of the Barranca de Estetes. Adjacent vegetation includes nopal (Opuntia sp.) and Chenopodiaceae-Amaranthaceae as well as Asteraceae, characteristic of perturbed areas. The $\delta^{13} \mathrm{C}$ ratios from horizons in this profile reflect two different sources: SOM (2A, $4 \mathrm{~A}, 4 \mathrm{AE}$, and $5 \mathrm{~A})$; and charred material recovered in situ from the soil/sedimentary matrix (3A, 3C, and 4A). No archaeological remains were found associated with this profile, useful for relating soil horizons to prehispanic or colonial occupations; however, charred specimens provide approximate dates that allow comparison with Tlajinga and Otumba (Table 1). The 5A horizon is the earliest for which $\delta^{13} \mathrm{C}$ ratios are available, indicating a value of -16.7 $\%$ (77.2 \% C4-CAMS). Phytoliths in this soil indicate a predominance of $\mathrm{C} 3$ grass taxa (62\%). A slight increase is evident in the 4AE horizon (-15.7 \%, 84.7\% C4-CAMS), whereas phytoliths again point to the predominance of $\mathrm{C} 3$ taxa $(61 \%)$. In $4 \mathrm{~A}$ a return to higher C4-CAMS is suggested by the $\delta^{13} \mathrm{C}$ values (-16.7 \%o, 77.2\% C4-CAMS), although the phytoliths recovered indicate $70 \% \mathrm{C} 3$ grass taxa. The $\delta^{13} \mathrm{C}$ ratio based on SOM, corresponding to the $2 \mathrm{~A}$ horizon (-17.7, 69.6 \% C4-CAMS), suggests a relative decline in C4-CAMS taxa with respect to the isotopic values in earlier soils. Phytoliths corresponding to the 3C, 3A and 2A horizons indicate a predominance of $\mathrm{C} 3$ grass taxa $(82$ $\%, 67 \%$ and $69 \%$ respectively).

The 4A soil also provides a date corresponding to the Aztec period, based on a charred specimen that clearly represents a $\mathrm{C} 3$ taxon $(-23.3 \%$ ). Similarly, the $3 \mathrm{C}$ and $3 \mathrm{~A}$ horizons are dated to the Aztec-Colonial period based on charred materials that represent $\mathrm{C} 3$ taxa $\left(\delta^{13} \mathrm{C}\right.$ values are 
a
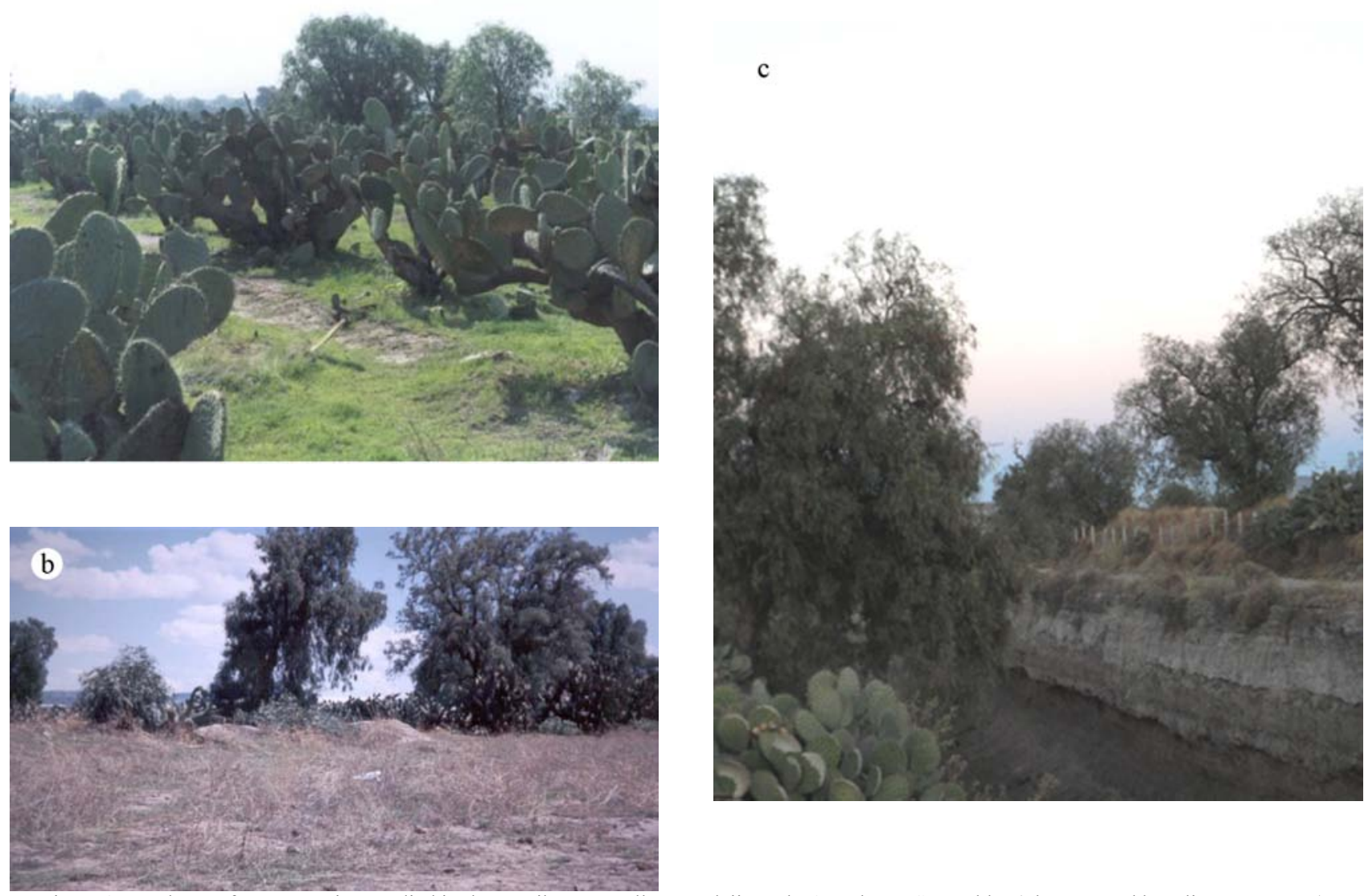

Figure 3. Landscape features at sites studied in the Teotihuacan Valley: a. Tlajinga; b. Otumba; c. San Pablo. (Photos a and b, Julia Pérez-Pérez).

$-24.2 \%$ and $-22 \%$ respectively).

\section{Discussion}

Based on $\delta^{13} \mathrm{C}$ ratios alone, we cannot effectively differentiate between $\mathrm{C} 4$ and CAMS plants, especially maize and xerophytic plants such as nopal (Opuntia spp.) and maguey (Agave spp.). In the central and NE sectors of the Teotihuacan Valley, C4 grasses and CAMS taxa are predominant today, but more favorable conditions for maize cultivation, particularly in association with the use of irrigation, were likely present during the Classic period as well as the Late Postclassic.

One potential limitation of the use of $\delta^{13} \mathrm{C}$ values from SOM in the study region to trace changes in vegetation through time is related to landscape dynamics and, particularly, the impact of erosion. Numerous polycyclic profiles in the Teotihuacan Valley show varying degrees of soil development, either with truncated sequences where part of the profile is no longer present, or superimposed sediments with inverted radiocarbon dates (McClung de Tapia et al., 2005). These upper sediments were the result of erosive events during which older soils from higher elevations, reworked and mixed with materials of different ages, were deposited at lower elevations. In addition, prehispanic irrigation systems contributed to the redeposition and remixing of sediments in Tlajinga and Otumba. At San Pablo, the river itself transported a large sediment load annually. Therefore, it is not entirely clear to what extent $\delta^{13} \mathrm{C}$ values represent a mixture of plant taxa characteristic of the original soils together with vegetation that developed on redeposited sediments at Tlajinga, Otumba and San Pablo.

$\delta^{13} \mathrm{C}$ ratios can be used to quantify aspects of vegetation dynamics in ecosystems, such as the changes in relative proportions of plants and, by association, the environmental conditions (e.g. temperature and humidity) within which they developed. In general, the isotopic signatures reported here indicate changes in relative proportions of $\mathrm{C} 3$ and C4-CAMS plants, suggesting variability in the response of vegetation to local conditions, with a predominance of $\mathrm{C} 4$ plants in soil organic matter. The chronological framework for such changes is difficult to reconstruct in the Teotihuacan Valley due to notable inversions in the ${ }^{14} \mathrm{C}$ dates (McClung de Tapia et al., 2005; Rivera-Uria et al., 2007, SolleiroRebolledo et al., 2011). The problems associated with interpretation of radiocarbon dates obtained from SOM 
in bulk sediment samples have been discussed elsewhere (McClung de Tapia et al., 2005). In this study, we were able to construct a broad chronological framework for three sites based on prehispanic and Colonial period ceramics recovered from the horizons together with radiocarbon dates on charred material in situ in the matrix of the buried soils and sediments.

From both a methodological and theoretical perspective, an entirely new set of problems is raised, demonstrating the complexity of human ecodynamics through time and implications for landscape reconstruction in the study region. One issue of importance is the extent to which $\delta^{13} \mathrm{C}$ ratios reflect in situ vegetation in re-deposited sediments or a mixture with original vegetation from higher elevations prior to erosion. An additional related problem to be addressed as research continues, is the chronology of the erosive events evident in the stratigraphic record.

Although phytoliths suggest overall a greater presence of $\mathrm{C} 3$ vegetation in San Pablo, pointing to regionally cooler and more humid conditions, it is likely that $\mathrm{C} 3$ taxa reflect the riparian environment characteristic of the river bank. The relatively higher proportion of C4-CAMS plants suggested by the isotope rations may be related to cultivated plants such as maize and nopal.

In this initial study, emphasis was placed on the comparison of horizons from three sites that appear to be culturally affiliated to the prehispanic and Colonial periods in the Teotihuacan Valley, in order to look at vegetation change and landscape transformaton during this period. However, future case studies are required to develop robust interpretations about the paleoenvironment. Furthermore, systematic measurements of modern environmental gradients, together with detailed assessments of soil formation processes are fundamental to achieve this goal.

\section{Acknowledgements}

Excavation at Tlajinga and Otumba were carried out by Julia Pérez Pérez as part of the investigation "Paleoenvironment of the Teotihuacan Valley". The research reported here received financial support from CONACYT $(25074 \mathrm{H})$ and PAPIIT/DGAPA-UNAM (IN405997 and IN400403) to Emily McClung de Tapia, Principal Investigator. The authors thank Jorge E. Gama-Castro and Bernhard Lucke for comments on an earlier version of this paper.

\section{References}

Biedenbender, S.H., McClaran, M.P., Quade, J.,Weltz, M.A., 2004, Landscape patterns of vegetation change indicated by soil carbón isotope composition: Geoderma, 119, 69-83.

Boutton, T., 1996, Stable carbon isotope ratios of soil organic matter and their use as indicators of vegetation and climatic change, in Boutton, T.W., Yamasaki, S. (eds.), Mass Spectrometry of Soils: New York, New York, USA, Marcel Dekker, Inc., 47-82.

Castilla-Hernández, M.E., Tejero-Diez, J.D., 1987, Flora y Vegetación del Cerro Gordo (San Juan Teotihuacan) y regiones aledañas, Valle de México, México: Biótica, 12, 231-255.

Charlton, T.H., 1990, Operation 12, Field 20, Irrigation system excavations: Preliminary Report on Recent Research in the Otumba City-State, in Mesoamerican Research Colloquium: , Department of Anthropology, The University of Iowa, Iowa City, Iowa, Charlton, T.H., Nichols, D.L. (eds.), 201-212.

Feranec, R.S., 2008, Using stable isotopes as an additional tool to understand ancient human environments: Coloquios de Paleontología, 58, 7-11.

Gould, F.W., Shaw, L.B., 1983, Grass Systematics, $2^{\text {nd }}$ Edition: College Station, Texas, Texas A\&M University Press, College Station, 412 p.

Hall, G., Woodborne, S., Scholes, M., 2008, Stable carbon isotope ratios from archaeological charcoal as paleoenvironmental indicators: Chemical Geology, 247, 384-400.

Hart, J.P., Lovis, W.A., Schulenberg, J.K., Urquhart, G.R., 2007, Paleodietary implications from stable carbon isotope analysis of experimental cooking residues: Journal of Archaeological Science, $34,804-813$.

Hart, J.P., Urquhart, G.R., Feranec, R.S., Lovis, W.A., 2009, Non-linear relationship between bulk $\delta^{13} \mathrm{C}$ and percent maize in carbonized cooking residues and the potential of false negatives in detecting maize: Journal of Archaeological Science, 36, 2206-2212.

Johnson, K.D., Wright, D.R., Terry, R.E., 2007, Application of carbon isotope analysis to ancient maize agriculture in the Petexbatún region of Guatemala: Geoarchaeology, 22, 313-336.

Kelly, E.F., Blecker, S.W., Yonker, C.M., Olson, C.G., Wold E.E., Todd, L.C., 1998, Stable isotope composition of soil organic matter and phytoliths as paleoenvironmental indicators: Geoderma, 82, 59-81.

Kerns, B.K., Moore, M.M., Hart, S.C., 2001, Estimating forest-grassland dynamics using soil phytolith assemblages and $\delta^{13} \mathrm{C}$ of soil organic matter: Écoscience, 8, 478-488.

Koch, L., 1998, Isotopic reconstruction of past continental environments: Annual Review of Earth and Planetary Science, 26, 573-613.

Lajtha, K., Marshall, J.D., 1994, Sources of variation in the stable isotopic composition of plants, in Lajtha,K., Michener, E.H. (eds.), Stable Carbon Isotopes in Ecology and Environmental Science, Oxford, United Kingdom, Blackwell Scientific Publications, 1-21.

Lounejeva-Baturina, E., Morales-Puente, P., Cabadas-Báez, H.V., Cienfuegos-Alvarado, E., Sedov, S., Vallejo-Gómez, E., SolleiroRebolledo, E., 2006, Late Pleistocene to Holocene environmental changes from $\delta^{13} \mathrm{C}$ determinations in soils at Teotihuacan, Mexico: Geofísica Internacional, 45, 85-98.

Lounejeva-Baturina, E., Morales-Puente, P., Cienfuegos-Alvarado, E., Sedov, S., Solleiro-Rebolledo, E., 2007, Late Quaternary environment in the Teotihuacan Valley, Mexico, Inferred from $\mathrm{d}^{13} \mathrm{C}$ in Soils: SAS Bulletin, 30, 6-11.

Madella, M., Power-Jones A., Jones M., 1998, A simple method of extraction of opal phytoliths from sediments using a non-toxic heavy liquid: Journal of Archaeological Science, 25, 801-803.

McClung de Tapia, E., Aguilar-Hernández, B., 2001, Vegetation and plant use in Postclassic Otumba: Ancient Mesoamerica, 12, 113-125.

McClung de Tapia, E., Solleiro-Rebolledo, E., Gama-Castro, J.,Villalpando, J.L., Sedov, S., 2003, Paleosols in the Teotihuacan valley, Mexico: evidence for paleoenvironment and human impact: Revista Mexicana de Ciencias Geológicas, 20, 270-282.

McClung de Tapia, E., Domínguez-Rubio, I., Gama-Castro, J., SolleiroRebolledo, E., Sedov, S., 2005, Radiocarbon dates from soil profiles in the Teotihuacan Valley, Mexico: indicators of geomorphological processes: Radiocarbon, 47, 159-175.

McClung de Tapia, E., Cabadas-Báez, H., Solleiro, E., Gama Castro, J., Vallejo, E., 2008, Phytoliths of soils and paleosols of the Teotihuacan Valley, Mexico, in Korstanje, A., Babot, M.P. (eds.), Interdisciplinary nuances in phytolith and other microfossil studies: Oxford, United Kingdom, BAR International Series, 67-76. 
Nichols, D.L., 1987, Prehispanic irrigation at Teotihuacan, New Evidence: the Tlajinga canals in McClung de Tapia, E., Rattray, E.C. (eds.), Teotihuacan. Nuevos Datos, Nuevas Síntesis, Nuevos Problemas: Cd. Universitaria, México, Instituto de Investigaciones Antropológicas, Universidad Nacional Autónoma de México, Mexico, 133-160.

Nichols, D.L., Spence,M., Borland, M., 1991, Watering the fields of Teotihuacan: Early irrigation at the ancient city: Ancient Mesoamerica, 2, 119-129.

Nordt, L., von Fischer,J., Tieszan, L., 2007, Late Quaternary temperature record from buried soils of the North American Great Plains: Geology, 35, 159-162.

Nordt, L., von Fischer, J., Tieszan, L., Tubbs, J., 2008, Coherent changes in relative $\mathrm{C} 4$ plant productivity and climate during the Late Quaternary in the North American Great Plains: Quaternary Science Reviews, $27,1600-1611$

Pearsall, D., 2000, Paleoethnobotany: a Handbook of Procedures (2 $2^{\text {nd }}$ Edition): San Diego, California, USA, Academic Press, $700 \mathrm{p}$.

Pérez-Pérez, J., 2003, La agricultura en Teotihuacan. Una forma de modificación al paisaje: Cd. Universitaria, México, Instituto de Investgaciones Antropológicas/Facultad de Folosofía y Letras, Universidad Nacional Autónoma de México, Master's thesis, 284 p.,

Pessenda, L.C.R., Gomes, B.M., Aravena, R., Ribeiro, A.S., Boulet R., Gouveia, S.E.M., 1998, The carbon isotope record in soils along a forest-cerrado ecosystem transect: implications for vegetation changes in the Rondonia state, southwestern Brazilian Amazon region: The Holocene, 8, 599-603.

Reimer., P.J, Baillie, M.G.L., Bard, E., Bayliss, A., Beck, J.W., Blackwell, P.G., Bronk Ramsey, C., Buck, C.E., Burr, G.S., Edwards, R.L., Friedrich, M., Grootes, P.M ., Guilderson, T.P., Hajdas, I., Heaton, T.J., Hogg, A.G., Hughen, K.A., Kaiser, K.F., Kromer, B., McCormac, F.G., Manning, S.W., Reimer, R.W., Richards, D.A., Southon, J.R., Talamo, S., Turney, C.S.M., van der Plicht, J., Weyhenmeyer, C.E., 2009, IntCa109 and Marine09 radiocarbon age calibration curves, $0-50000$ years cal BP: Radiocarbon, $51,1111-1150$.

Rivera-Uria, M.Y., Sedov, S., Solleiro-Rebolledo, E., Pérez-Pérez, J., McClung, E., González, A., Gama-Castro, J., 2007, Degradación ambiental en el valle Teotihuacan: evidencias geológicas y paleopedológicas: Boletín de la Sociedad Geológica Mexicana, 59, 203-217.

Seinfeld, D.M., von Nagy, C., Pohl, M.D., 2009, Determining Olmec maize through bulk stable carbon isotope analysis: Journal of Archaeological Science, 36, 2560-2565.
Solleiro-Rebolledo, E., Syncheva, S., Sedov, S., McClung de Tapia, E., Rivera-Uria, Y., Salcido-Berkovich, C., Kuznetsova, A., 2011, Fluvial processes and paleopedogenesis in the Teotihuacan Valley, Mexico: Responses to late Quaternary environmental changes: Quaternary International, 233, 40-52.

Stuiver, M., Reimer, P.J., 1993, Extended ${ }^{14} \mathrm{C}$ database and revised CALIB radiocarbon calibration program: Radiocarbon, 35, 215-230. Calib version 6.0 (calib.qub.ac.uk, accessed 25-XI-2011).

Vågen, T.G, Walsh, M., Shepherd, K.D., 2006, Stable isotopes for characterization of trends in soil carbon following deforestation and land use change in the highlands of Madagascar: Geoderma, $135,133-139$.

Wang, L., D’Odorico, P., Ries, L., Macko, S.A., 2010, Patterns and implications of plant-soil $\delta^{13} \mathrm{C}$ and $\delta^{15} \mathrm{~N}$ values in African savanna ecosystems: Quaternary Research, 73, 77-83.

Watson, L., Dallwitz, M.J., 1992 onwards, The grass genera of the world: descriptions, illustrations, identification, and information retrieval; including synonyms, morphology, anatomy, physiology, phytochemistry, cytology, classification, pathogens, world and local distribution, and references, Institute of Botany, Chinese Academy of Sciences, http://delta-intkey.com, April $23^{\text {rd }}, 2010$.

Webb, E.A., Schwarcz, H.P., Healy, P.F., 2004, Detection of ancient maize in lowland Maya soils using stable carbon isotopes: evidence from Caracol, Belize: Journal of Archaeological Science, 31, 1039-1052.

Webb, E.A., Schwarcz, H.P., Jensen, C.T., Terry, R.E., Moriarty, M.D., Emery, K.F., 2007, Stable Carbon isotope signature of ancient maize agriculture in the soils of Motul de San José, Guatemala: Geoarchaeology, 22, 291-312.

Wright, D.R., 2005, Soil stable carbon isotope analysis of landscape features at Aguateca, Guatemala: Salt Lake City, Utah, USA, Department of Plant and Animal Science, Brigham Young University, MSc. thesis, $130 \mathrm{p}$.

Manuscript received: December 20, 2010.

Corrected manuscript received: June 15, 2011.

Manuscript accepted: November 15, 2011. 